\title{
WISSARD at Subglacial Lake Whillans, West Antarctica: scientific operations and initial observations
}

\author{
Slawek TULACZYK, ${ }^{1}$ Jill A. MIKUCKI, ${ }^{2}$ Matthew R. SIEGFRIED, ${ }^{3}$ John C. PRISCU, ${ }^{4}$ \\ C. Grace BARCHECK, ${ }^{1}$ Lucas H. BEEM, ${ }^{1}$ Alberto BEHAR, ${ }^{5}$ Justin BURNETT, ${ }^{6}$ \\ Brent C. CHRISTNER, ${ }^{7}$ Andrew T. FISHER, ${ }^{1}$ Helen A. FRICKER, ${ }^{3}$ \\ Kenneth D. MANKOFF, ${ }^{1}$ Ross D. POWELL, ${ }^{8}$ Frank RACK, ${ }^{6}$ Daniel SAMPSON, ${ }^{1}$ \\ Reed P. SCHERER, ${ }^{8}$ Susan Y. SCHWARTZ ${ }^{1}$ and THE WISSARD SCIENCE TEAM ${ }^{9}$ \\ ${ }^{1}$ Department of Earth and Planetary Sciences, University of California Santa Cruz, Santa Cruz, CA, USA \\ E-mail: stulaczyk@ucsc.edu \\ ${ }^{2}$ Department of Microbiology, University of Tennessee, Knoxville, TN, USA \\ ${ }^{3}$ Institute of Geophysics and Planetary Physics, Scripps Institution of Oceanography, University of California, San Diego, \\ La Jolla, CA, USA \\ ${ }^{4}$ Department of Land Resources and Environmental Science, Montana State University, Bozeman, MT, USA \\ ${ }^{5}$ Jet Propulsion Laboratory, California Institute of Technology, Pasadena, CA, USA \\ ${ }^{6}$ Antarctic Geological Drilling Science Management Office, University of Nebraska, Lincoln, NE, USA \\ ${ }^{7}$ Department of Biological Sciences, Louisiana State University, Baton Rouge, LA, USA \\ ${ }^{8}$ Geology and Environmental Geosciences, Northern Illinois University, DeKalb, IL, USA \\ ${ }^{9}$ Full personnel list at http://www.wissard.org/about/wissard-personnel
}

\begin{abstract}
A clean hot-water drill was used to gain access to Subglacial Lake Whillans (SLW) in late January 2013 as part of the Whillans Ice Stream Subglacial Access Research Drilling (WISSARD) project. Over 3 days, we deployed an array of scientific tools through the SLW borehole: a downhole camera, a conductivity-temperature-depth (CTD) probe, a Niskin water sampler, an in situ filtration unit, three different sediment corers, a geothermal probe and a geophysical sensor string. Our observations confirm the existence of a subglacial water reservoir whose presence was previously inferred from satellite altimetry and surface geophysics. Subglacial water is about two orders of magnitude less saline than sea water (0.37-0.41 psu vs $35 \mathrm{psu}$ ) and two orders of magnitude more saline than pure drill meltwater $(<0.002 \mathrm{psu})$. It reaches a minimum temperature of $-0.55^{\circ} \mathrm{C}$, consistent with depression of the freezing point by 7.019 MPa of water pressure. Subglacial water was turbid and remained turbid following filtration through $0.45 \mu \mathrm{m}$ filters. The recovered sediment cores, which sampled down to $0.8 \mathrm{~m}$ below the lake bottom, contained a macroscopically structureless diamicton with shear strength between 2 and $6 \mathrm{kPa}$. Our main operational recommendation for future subglacial access through water-filled boreholes is to supply enough heat to the top of the borehole to keep it from freezing.
\end{abstract}

KEYWORDS: Antarctic glaciology, ice streams, subglacial lakes, subglacial processes, subglacial sediments

\section{INTRODUCTION}

Antarctic subglacial lakes represent important targets for scientific exploration because they may harbor unique and biogeochemically important microbial ecosystems (Priscu and others, 1999, 2008; Siegert and others, 2003; Siegert, 2005; Christner and others, 2006), help determine ice-sheet dynamics (Bell and others, 2007; Stearns and others, 2008; Beem and others, 2014; Siegfried and others, 2014) and contain sedimentary paleoenvironmental and paleoclimatic records (Hodgson and others, 2009; Bentley and others, 2013). There are already several hundred known subglacial lakes in Antarctica, including the so-called active lakes experiencing fill-and-drain cycles (Gray and others, 2005; Siegert and others, 2005; Wingham and others, 2006; Smith and others, 2009). The glaciological, geological and hydrological settings of these lakes appear to be variable and may result in significant differences in subglacial lacustrine conditions (e.g. Dowdeswell and Siegert, 2002).

Subglacial Lake Whillans (SLW) is located beneath the Whillans Ice Plain, which is fed by Mercer and Whillans Ice
Streams on the upstream end and discharges into Ross Ice Shelf (Fig. 1a). It belongs to a group of active subglacial lakes discovered based on anomalous ice elevation changes (Fricker and others, 2007). SLW was targeted for drilling by the Whillans Ice Stream Subglacial Access Research Drilling (WISSARD) project. The reasons for its selection as the drilling target have been detailed in previous publications (e.g. Priscu and others, 2010; Fricker and others, 2011). Recently, Priscu and others (2013) reported on the cleanaccess technologies and procedures.

The WISSARD project includes an extensive glaciological component focused on monitoring active subglacial lakes using a network of continuous GPS (cGPS) stations (e.g. Beem and others, 2014). One of these cGPS units was placed over SLW in December 2007 and captured one filling-draining cycle in 2008/09 with amplitude of $\sim 4 \mathrm{~m}$ (Fig. 1b). Since this event the cGPS on SLW has traveled upward at a slow rate, indicating that the lake was close to its most drained state at the time of drilling in late January 2013. 

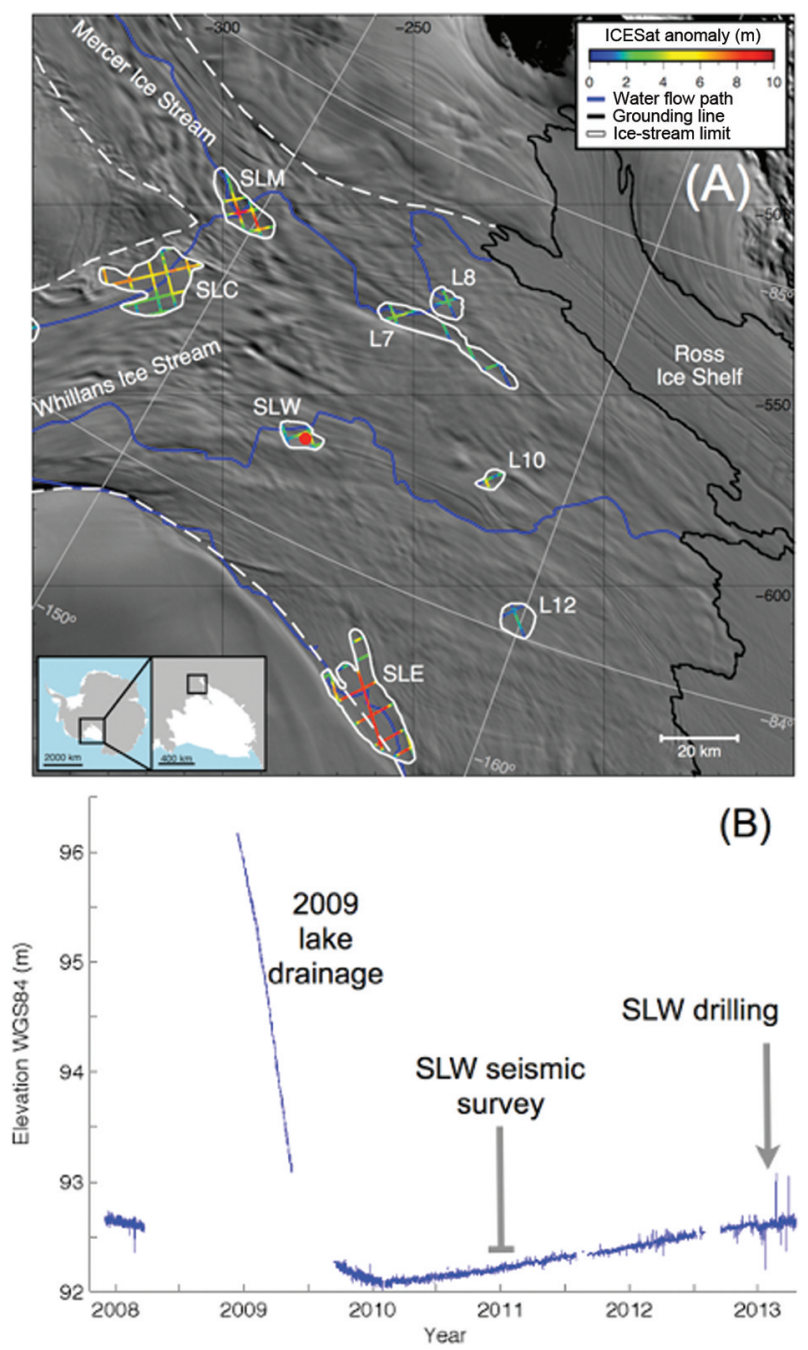

Fig. 1. (a) Overview of the Whillans Ice Plain, with inferred subglacial water flow paths indicated by blue lines (Carter and others, 2013) and subglacial lake outlines by solid white lines (SLC: Subglacial Lake Conway; SLM: Subglacial Lake Mercer; SLW: Subglacial Lake Whillans; SLE: Subglacial Lake Engelhardt; L7: Lake 7; L8: Lake 8; L10: Lake 10; and L12: Lake 12). The red dot on SLW indicates the borehole location. Ice, Cloud and land Elevation Satellite (ICESat) elevation change anomaly amplitudes and lake outlines are from Fricker and Scambos (2009); background imagery and grounding lines (black) come from the Moderate Resolution Imaging Spectroradiometer (MODIS) Mosaic of Antarctica (Scambos and others, 2007); and the lateral limits of fast ice flow (dashed white lines) are derived from Rignot and others (2011). Projection is south polar stereographic $(\mathrm{km})$ with standard latitude at $71^{\circ} \mathrm{S}$. (b) The vertical ice motion between late 2007 and early 2013 based on data from a GPS station located $\sim 700 \mathrm{~m}$ from the SLW borehole at the time of drilling. The 2009 lake drainage (Siegfried and others, 2014), timing of SLW active-source seismic survey (Horgan and others, 2012) and SLW drilling are labeled for reference.

As part of preparations for site selection and drilling, a surface geophysical survey of SLW was conducted in the 2010/11 austral summer. Detailed kinematic GPS and icepenetrating radar surveys revealed that SLW corresponds to a $\sim 15 \mathrm{~m}$ depression in ice surface topography and $>80 \mathrm{kPa}$ low in the regional subglacial water-pressure field, as estimated from ice surface and bed topography data (Christianson and others, 2012). Active-source seismic investigations over SLW confirmed that the basal reflection coefficient is consistent with the presence of a subglacial

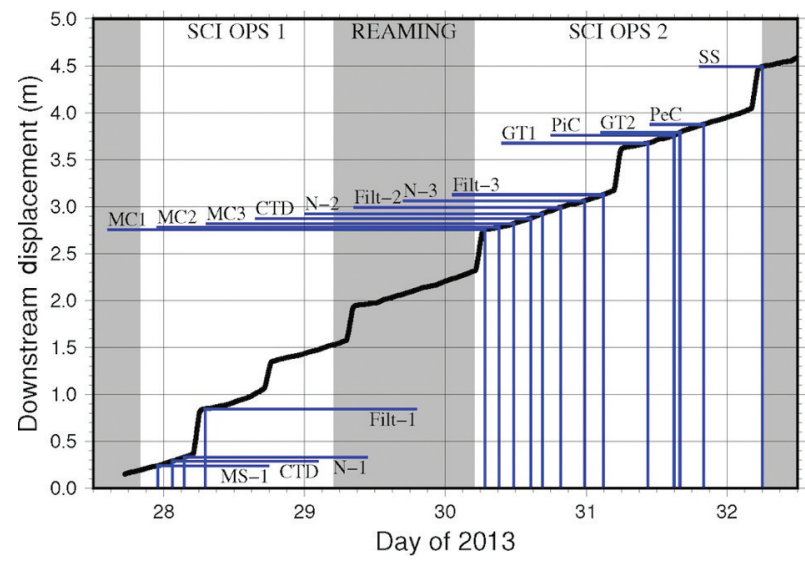

Fig. 2. Timeline of borehole operations and horizontal ice movement between 28 January and 1 February 2013. Ice motion is based on data from the same GPS station shown in Figure 1b. Due to small horizontal strain rates in the region, a station located $\sim 700 \mathrm{~m}$ from the SLW borehole is representative for the borehole location itself (Beem and others, 2014). The step-wise nature of ice motion is due to the well-known stick-slip behavior of the ice stream (Bindschadler and others, 2003; Walter and others, 2011). Sampling tools shown in the timeline include a borehole camera (MS1), a CTD probe, a Niskin bottle $(\mathrm{N \# )}$, an in situ water filtration unit (Filt\#), a sediment multicorer (MC\#); a geothermal probe (GT\#), a sediment piston corer $(\mathrm{PiC})$, a sediment percussion corer $(\mathrm{PeC})$ and a geophysical sensor string (SS). Gray shading represents periods when borehole was not used for science operations due to drilling, reaming, or end of season.

water reservoir and revealed a bowl-shaped sub-ice reflector interpreted as the lake bottom (Horgan and others, 2012).

Based on these geophysical results, the site with the thickest inferred subglacial water column was selected as the SLW drilling location for the $2012 / 13$ field season $\left(84.240^{\circ}\right.$ S, $\left.153.694^{\circ} \mathrm{W}\right)$. In this paper, we describe scientific operations which took place in the SLW borehole in the course of $\sim 3$ days at the end of January 2013 (Fig. 2). We also report initial observations describing conditions encountered in the SLW borehole, subglacial water and underlying sediments.

\section{BOREHOLE OPERATIONS}

\section{Selected aspects of borehole completion}

Figure 2 shows the timeline of scientific operations following borehole completion on 27 January 2013, at $\sim 8$ PM local time (all times are given here in coordinated universal time $($ UTC) $+12 \mathrm{~h}$ ). Although drilling operations are not the focus here, we discuss some aspects that are particularly relevant to scientific measurements and sample collection.

The WISSARD hot-water drill made a connection to the base of the ice sheet at 8:04 AM on 27 January 2013. About an hour before the anticipated breakthrough, water level in the borehole was pumped down to $\sim 110 \mathrm{~m}$ below ice surface to make sure that borehole water pressure was lower than SLW water pressure. The flotation pressure was calculated to be equivalent to borehole water level at $\sim 80 \mathrm{~m}$ below surface, based on the best estimate of ice thickness of $802 \pm 10 \mathrm{~m}$, from active-source seismic data (Horgan and others, 2012). An independent estimate of ice thickness from ground-based radar surveys yielded $797 \pm 10 \mathrm{~m}$ (Christianson and others, 2012). The flotation level was calculated from ice thickness following the approach of Engelhardt and Kamb (1997). 


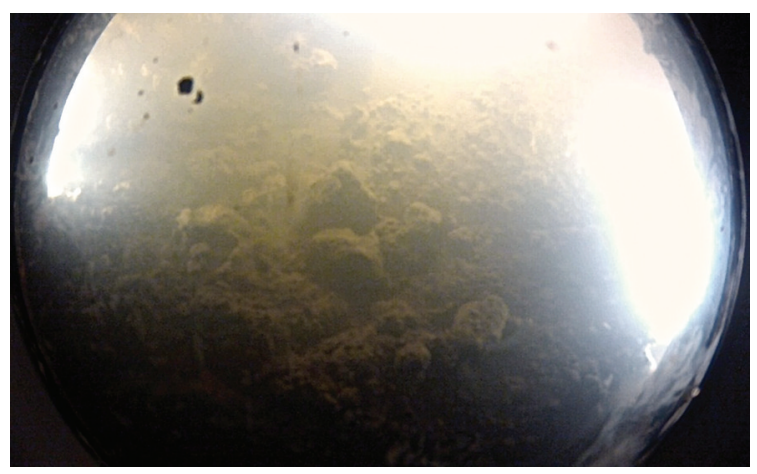

Fig. 3. Image of sediments at the bottom of SLW obtained by the MSLED camera. The top of the sedimentary layer crumbled as the camera housing touched it. The view shown here is nearly vertically down and the housing window is $\sim 0.3 \mathrm{~m}$ in diameter.

Recordings from a water-pressure transducer installed near the return water pump show that, at the time of the breakthrough, water rose within $<1 \mathrm{~min}$ by $28 \mathrm{~m}$. The transducer output was recorded by the drill control software at $1 \mathrm{~min}$ intervals, but the real-time visual output to the command center display took place at $1 \mathrm{~s}$ intervals. The drill operator at the time noted that the main phase of borehole water-level adjustment occurred in just $2 \mathrm{~s}$. This rapid equilibration contrasts with minutes-long breakthroughs observed by Engelhardt and Kamb (1997) in boreholes drilled on various Siple Coast ice streams.

If the borehole is assumed to have a simple cylindrical shape with the design radius of $0.3 \mathrm{~m}$ then $\sim 8 \mathrm{~m}^{3}$ of lake water rushed into the borehole from the subglacial environment during breakthrough. However, the volume of the upper part of the borehole, which determines how much water must enter to equilibrate water pressure to the flotation level, was likely larger than a simple cylinder because a parallel but interconnected return pump borehole was drilled right next to the main SLW hole. At the point of breakthrough, the drill nozzle flow was at a low level of just less than $1 \mathrm{~L} \mathrm{~min}^{-1}$. It was lowered from its normal level of $\sim 115 \mathrm{~L} \mathrm{~min}^{-1}$ at 7:20 AM in anticipation of the breakthrough. Seven minutes after breakthrough the drill flow rate was increased to $135 \mathrm{~L} \mathrm{~min}^{-1}$, and the process of borehole reaming back to the top lasted until 7:40 PM.

\section{Borehole camera}

Following its completion, the SLW borehole was visually inspected to determine if it could be used to deploy our scientific equipment. We used a borehole camera, which is part of the Micro-Submersible Lake Exploration Device (MSLED) (MS1 in Fig. 2). It consists of a cylindrical pressure housing with lights around its rim and a down-looking GoPro Hero 3 camera sending video to the surface through a Kevlar-reinforced fiber-optic cable with length markings. The camera enabled real-time visual inspection of the SLW borehole and subglacial cavity (Fig. 3).

\section{Conductivity-temperature-depth (CTD) profiler}

After visual assessment of borehole quality, we deployed a CTD profiler, Sea-Bird SBE 19 plus V2. We used conductivity and temperature data to calculate water salinity based on the equation of state for water (EOS-80, Sea-Bird Electronics, 2013) (Fig. 4). For low-salinity waters, accuracy is reported as being at the level of \pm 0.005 psu (practical

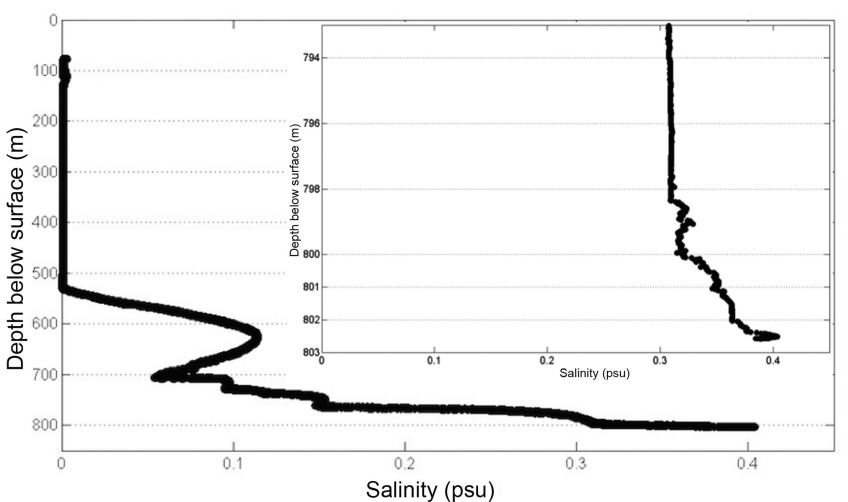

Fig. 4. Vertical profile of salinity from a CTD cast run in early hours of 28 January 2013. Measurements were taken at $0.25 \mathrm{~s}$ intervals. The inset shows details of salinity measured in the lowermost $10 \mathrm{~m}$. For consistency, the salinity scale in the inset is kept within the same range as in the main figure. Depth below surface is obtained by adding $78 \mathrm{~m}$ to the pressure-based estimate of depth provided by the CTD.

salinity units). Sea-Bird cites accuracy for temperature measurements with this $\mathrm{CTD}$ model as $\pm 0.005^{\circ} \mathrm{C}$, and we give all temperatures to $\pm 0.01{ }^{\circ} \mathrm{C}$. Water density is calculated using salinity, temperature and pressure as inputs for the EOS-80 equation of state. Once density is known, the CTD data provide a depth estimate, from pressure measurements, the calculated water density, and the acceleration of gravity corrected for latitude (Sea-Bird Electronics, 2013). Based on accuracies of the individual measurements reported by the manufacturer, we estimate the absolute error on calculated depth to be $<0.1 \%$ of total depth value (i.e. $<0.7 \mathrm{~m}$ for $700 \mathrm{~m}$ ). Small standard deviation of depth values, $\sim 0.05 \mathrm{~m}$, obtained when the CTD was resting at the lake bottom suggests a much better relative depth resolution, so we later report estimates of lake depth to within $0.1 \mathrm{~m}$.

\section{Water sampling}

Recovery of subglacial water samples from SLW for biological and chemical analyses was one of the primary scientific objectives of the WISSARD project (Fricker and others, 2011). The key tool used for this purpose was a hydrogen peroxide (3\%) cleaned $10 \mathrm{~L}$ Niskin sampling bottle (Niskin and others, 1973). One Niskin bottle cast was performed immediately after the initial CTD deployment and two more during the second period of scientific operations (Fig. 2). A Niskin bottle was lowered into the borehole until the winch load cell indicated that the weight hanging $0.25 \mathrm{~m}$ below the bottle touched the lake bottom. Particles and cells suspended in water were sampled using a down-hole in situ filtration unit built by McLane Research Laboratories, Inc. (Fig. 5). As seen by the particulate matter on the $0.2 \mu \mathrm{m}$ filter in this figure, subglacial water still contained significant suspended particles, which is consistent with the visual observations made after the borehole was completed. The finest filter size on the McLane unit is $0.2 \mu \mathrm{m}$, with two coarser pre-filters, $3 \mu \mathrm{m}$ and $10 \mu \mathrm{m}$.

\section{Sediment coring}

The first corer we deployed in the SLW borehole was the UWITEC gravity multi-corer. It consists of three $60 \mathrm{~mm}$ diameter, $50 \mathrm{~cm}$-long sampling tubes with automatic core catchers and is designed to enable sampling of soft 


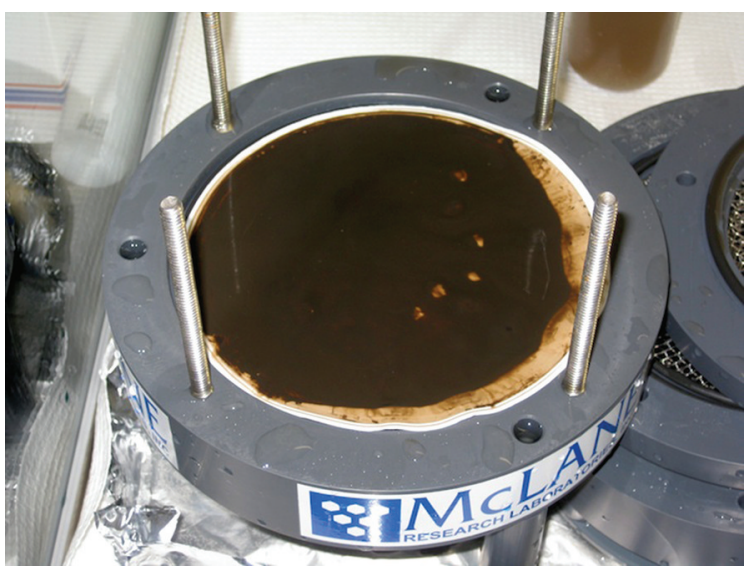

Fig. 5. Fine-grained sediments collected on the finest filter, $0.2 \mu \mathrm{m}$, of the McLane in situ filtration unit.

sediments with preservation of the sediment/water interface. The entire assembly is relatively large, not streamlined, and quite light. Consequently, we experienced seven unsuccessful attempts at deploying the multi-corer because it either got stuck in the borehole or could not advance beyond the ice layer that formed at the air/water interface. Given these problems, the decision was made to put the drill back into the SLW borehole for an up-and-down ream cycle which lasted for $\sim 24$ hours (Fig. 2).

Sediment coring was the key objective for the second phase of scientific borehole operations at SLW (Fig. 2). The NIU multi-corer was deployed immediately after borehole reaming, and on three deployments it returned two sediment cores in each run (Fig. 6). The cores were up to $0.4 \mathrm{~m}$ in length. One of the multi-corer samples was used to collect pore waters for chemical analyses using Rhizon samplers (Seeberg-Elverfeldt and others, 2005). Later, in the second phase of scientific operations, we deployed the borehole piston corer with a $3 \mathrm{~m}$-long barrel. It collected a $0.8 \mathrm{~m}$-long core with a diameter of $58 \mathrm{~mm}$.

The third sediment corer used was the $10 \mathrm{~cm}$ diameter, $5 \mathrm{~m}$-long percussion corer. Due to malfunction of its smart winch, this was used essentially as a gravity corer, and collected $0.4 \mathrm{~m}$-long samples. Between the first multi-corer deployment and the sampling with the percussion corer, the SLW borehole moved by $\sim 1 \mathrm{~m}$ horizontally (Fig. 2 ).

\section{Geothermal probe}

It is difficult to constrain geothermal fluxes from basal temperature profiles measured in boreholes drilled in ice, and such estimates are associated with large uncertainties (e.g. supplementary material for WAIS Divide Project Members, 2013). Antarctic geothermal flux distribution is crucial to understanding the tectonic evolution of Antarctica, the dynamics of its ice sheet, and its subglacial hydrology, but it is only constrained by geophysical models, which yield quite disparate results (cf. Shapiro and Ritzwoller, 2004; Maule and others, 2005). The geothermal probe was designed to penetrate sediments at the bottom of SLW and measure precisely the vertical temperature gradient (Fisher and others, 2003; Heesemann and others, 2006). In combination with direct laboratory measurements of thermal conductivity on sediment samples, the observed subglacial vertical temperature gradient will be used to calculate geothermal flux.

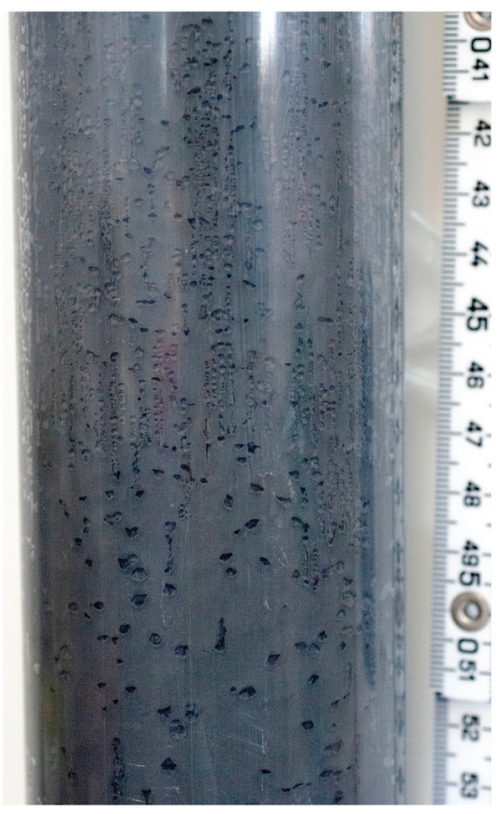

Fig. 6. Multi-corer sediment core in a transparent liner with a ruler in centimeters on the right-hand side. The dark spots are interpreted as gas bubbles formed as a result of core depressurization as it is brought up to the surface (Tulaczyk and others, 2001).

\section{Borehole sensor string}

Installation of the borehole sensor string early on 1 February 2013 represented the final stage of scientific operations in the SLW borehole. The string contains one three-axes borehole seismometer (Geosig), three vertical-axes geophones (one at the very bottom of the string, one $100 \mathrm{~m}$ above and one $600 \mathrm{~m}$ from the bottom) plus an $800 \mathrm{~m}$-long fiber-optic distributed temperature sensor (DTS). Due to environmental stewardship, the bottom of the string was installed $\sim 20 \mathrm{~m}$ above the ice base, rather than all the way to the bed. The lowest point of the string corresponds to the bottom of the DTS and contains the Geosig borehole seismometer as well as one of the geophones. The sensor string was left to freezein, and the top of the borehole was covered for safety. Power and data connections for the borehole sensors are located on the surface. Both seismic sensors and the DTS survived the borehole freezing process, and data were collected from them during the 2013/14 season.

\section{DISCUSSION}

\section{Operational issues}

Whereas the WISSARD Science Team planned for the potential risk of borehole diameter shrinkage due to refreezing, formation of ice at the top of the borehole was not managed. Consequently, scientific operations in the SLW borehole were impacted by freezing at the air/water interface.

To mitigate the risk from lateral borehole refreezing, we requested a borehole diameter which exceeded by $>0.2 \mathrm{~m}$ the diameter of our largest scientific equipment. Moreover, the planned scientific borehole timeline prioritized, whenever there were no overriding scientific considerations, the large-diameter tools. Based on Koci (1984, fig. 4), we estimated that borehole freezing rates would decrease from $\sim 8 \mathrm{~cm} \mathrm{~d}^{-1}$ on day one to about $4 \mathrm{~cm} \mathrm{~d}^{-1}$ on day four for the 
mean annual temperature of $-25^{\circ} \mathrm{C}$ at the SLW site. Freezing rates should decrease to nil at the base, where ice temperature is near its pressure-melting point (Engelhardt, 2004).

Freezing at the top of the SLW borehole water column resulted in significant disturbance to the planned operational sequence, but we found no quantitative treatment of this problem in published literature. A simple equation quantifying the growth in ice thickness, $h$, is given by Stefan (1891):

$$
h_{(t)}=\sqrt{\frac{2 K_{\mathrm{i}} \Delta T t}{L \rho}}
$$

where $K_{\mathrm{i}}$ is the thermal conductivity of ice $\left(2.1 \mathrm{~W} \mathrm{~m}^{-1}{ }^{\circ} \mathrm{C}^{-1}\right)$, $\Delta T$ is the difference between the freezing point of water and air temperature right above the ice layer, $t$ is time, $L$ is the latent heat of freezing $\left(333.5 \mathrm{~kJ} \mathrm{~kg}^{-1}\right)$ and $\rho$ is density $\left(917 \mathrm{~kg} \mathrm{~m}^{-3}\right)$. Equation (1) shows that in just one day, the ice layer reaches $\sim 0.03 \mathrm{~m}$ thickness, with air temperature being just $1{ }^{\circ} \mathrm{C}$ below freezing. Data from the geothermal probe, which was deployed about a day after borehole reaming, show that air temperature in the borehole was below $-4^{\circ} \mathrm{C}$.

Lake ice studies indicate that the load capacity of an ice layer scales with the square of its thickness (Bealtos, 2002):

$$
F=C_{i} h^{2}
$$

where $F$ is the 'safe' short-term load $(\mathrm{kN})$ and $C_{i}$ is an empirical constant with units of stress, given by Bealtos (2002, p. 206) as $1790 \mathrm{kPa}$. Equation (2) has been developed and calibrated for horizontally extensive ice layers, whereas we consider an ice layer in a borehole with radius $R$. However, it should still be applicable as long as $h \ll R$. Even if we take $h=0.03 \mathrm{~m}$, as calculated above, such a layer can support a piece of equipment with mass of $\sim 200 \mathrm{~kg}$.

Growth of an ice layer at the top of a water-filled borehole can be hindered by supplying hot water at the water/air interface. It is sufficient to keep an ice layer thin enough so that it can be penetrated by even light instrumentation. For instance, a $0.002 \mathrm{~m}$-thick ice layer will be broken by a mass greater than $2 \mathrm{~kg}$. The rate of hot-water input, $q\left(\mathrm{~kg} \mathrm{~s}^{-1}\right)$, needed to balance conductive heat loss through an ice layer of thickness $h$ can be estimated from

$$
q=\frac{\Delta T}{h} \frac{K_{\mathrm{i}}}{C_{p}} \frac{\pi R^{2}}{T_{\mathrm{dw}}}
$$

where the first ratio on the right-hand side represents a linear temperature gradient across the ice layer, the second term is the ratio of ice thermal conductivity to heat capacity of water $\left(c_{p}=4218 \mathrm{~J} \mathrm{~kg}^{-1} \mathrm{~K}^{-1}\right)$ and the third term is the ratio of borehole area to the temperature of drill water, $T_{\mathrm{dw}}$. Even for $\Delta T=-20^{\circ} \mathrm{C}$, it would take just $1 \mathrm{~L} \mathrm{~min}{ }^{-1}$ of drill water with a temperature of $85^{\circ} \mathrm{C}$ to keep an ice layer from growing beyond $0.002 \mathrm{~m}$ thickness in a borehole of $0.6 \mathrm{~m}$ diameter. However, this would mean deploying an additional hose into the borehole, which could risk entanglement with instruments being deployed down-hole.

\section{Water properties and lake depth}

Our first opportunity to examine the transition from borehole water to subglacial water came during the deployment of the MSLED camera (Fig. 2). It went through the air/water interface $78 \mathrm{~m}$ below the ice surface. Borehole water first appeared turbid at $\sim 520 \mathrm{~m}$ depth, and turbidity increased markedly near the bottom of the borehole. High turbidity made it difficult to determine the depth to the ice base, which was picked to be at $\sim 800 \mathrm{~m}$ below surface based on decrease in image brightness, presumed to be due to camera lights no longer reflecting from borehole walls. After an estimated $1.6 \mathrm{~m}$ of additional cable pay-out, the camera rested on the lake bottom, imaging the top of relatively soft sediments (Fig. 3). It is difficult to quantify the uncertainty on this visual water depth estimate. Below we use CTD data as an additional constraint.

Figure 4 shows the vertical profile of salinity (psu), including a detailed view of the lowermost $10 \mathrm{~m}$ of the borehole. For reference, standard sea-water salinity is 35 on the psu scale, whereas the maximum salinity in Figure 4 is almost 100 times lower. Hence, all water encountered by the CTD, including the subglacial cavity water, is quite fresh, with subglacial water being similar in salinity to a lower Colorado River reservoir. Pure meltwater generated during drilling has nil salinity, with psu values staying at the limit of detectability $(<0.002 \mathrm{psu})$ above $530 \mathrm{~m}$ water depth. This observation is consistent with the very low ion concentration found in the Siple Dome ice core (MacGregor and others, 2007).

The average salinity of borehole water below $530 \mathrm{~m}$ is $0.28 \mathrm{psu}$, about three orders of magnitude higher than the salinity of drill meltwater. Assuming that this average salinity resulted from mixing of drill meltwater (0.002 psu) with subglacial water $(0.37-0.41 \mathrm{psu})$ (Fig. 4), then the latter constitutes $25-27 \%$ of borehole water below $530 \mathrm{~m}$. If the average borehole diameter was the design diameter of $0.6 \mathrm{~m}$, then we estimate that about $20 \mathrm{~m}^{3}$ of subglacial water entered the borehole before our first CTD cast. This value exceeds our prior estimate of $8 \mathrm{~m}^{3}$ entering the borehole during the drill breakthrough. The initial influx may have been at the $20 \mathrm{~m}^{3}$ level because of the presence of the return pump borehole next to the main hole, or subglacial water continued to enter the borehole during reaming.

The total water column depth measured by the CTD when it was resting at the bottom of SLW was $724.6 \pm 0.7 \mathrm{~m}$. This means that the lake bottom was $802.6 \pm 0.8 \mathrm{~m}$ below ice surface. As the CTD was being lowered into the borehole, water salinity had very low scatter down to $798.4 \pm 0.8 \mathrm{~m}$ below the surface. A distinct kink in the salinity curve is seen at $\sim 800 \mathrm{~m}$. Analysis of the corresponding CTD water temperature data, not shown here, indicates an approximately isothermal water layer in the lowermost $2.2 \mathrm{~m}$ of the record. Based on these salinity and temperature data, we interpret that the subglacial water layer was $2.2 \mathrm{~m}$ thick beneath the SLW borehole. This is slightly higher than the $1.6 \mathrm{~m}$ water thickness estimated with the borehole camera.

The minimum water temperature of $-0.55^{\circ} \mathrm{C}$ was recorded in the borehole by the CTD unit at a pressure of $7019 \pm 7 \mathrm{kPa}$ (Sea-Bird Electronics, 2013) and salinity of $0.31 \mathrm{psu}$. With salinity at $<1 \%$ of sea-water salinity, at most $0.02{ }^{\circ} \mathrm{C}$ of freezing-point depression can be due to solutes. Most of the observed depression, about $-0.53^{\circ} \mathrm{C}$, is attributable to the pressure dependence of the freezing point, with a proportionality coefficient of $75.5 \times 10^{-8} \mathrm{CPa}^{-1}$. This coefficient is within $2 \%$ of the value of $74.2 \times 10^{-8 \circ} \mathrm{CPa}^{-1}$ given by Cuffey and Patterson (2010) for pure water. This slight discrepancy may result from the presence of dissolved gas in subglacial water (Fig. 6; Tulaczyk and others, 2001). 


\section{Subglacial cavity and its sedimentary environment}

Radar and seismic geophysical surveys provided evidence for the presence of a subglacial water layer with horizontal extent corresponding closely to the footprint of SLW inferred previously from ice surface elevation changes (Fricker and others, 2007; Fricker and Scambos, 2009; Christianson and others, 2012; Horgan and others, 2012). Borehole observations yield direct confirmation that this water layer interpreted from remote-sensing and surface geophysical data does exist in the study area. However, they do not confirm the inference drawn from active-source seismic profiling that the subglacial water column is $8 \pm 2 \mathrm{~m}$ thick at the drill site (Horgan and others, 2012, fig. 7). This discrepancy is difficult to explain by changes in lake thickness in the 2 years between seismic surveys and drilling (Fig. 1b).

This opportunity to double-check Antarctic subglacial conditions inferred from surface active-source seismic investigations represents a cautionary note that emphasizes the resolution limitations and potential non-uniqueness of geophysical methods. Conceivably, SLW depth distribution is sufficiently variable on horizontal scales smaller than the resolution of the seismic survey, $\sim 180 \mathrm{~m}$ (Horgan and others, 2012, p. 203), for the borehole to encounter a local high in the lake bed that is not resolvable in the seismic data. Alternatively, limits on vertical resolution may have made it impossible to distinguish between the thin water layer and relatively soft subglacial sediments with similar seismic velocities.

We conjecture that the bowl-shaped sub-ice reflector imaged by Horgan and others (2012) may not represent the bottom of a water body but a boundary between the relatively porous and weak sediments cored by us and some denser and/or more rigid geologic substratum. Given its geometry and spatial coincidence with the surface expression of SLW, it is plausible that this reflector delineates an erosional boundary which used to be the bottom of the lake. Over time this shallow basin may have become largely filled with sediments.

The sediment cores recovered from SLW are composed of a macroscopically structureless diamicton and are similar to the subglacial tills recovered previously from beneath Siple Coast ice streams (Scherer and others, 1998; Tulaczyk and others, 1998, 2000). Sediment shear strength, measured in June 2013 on a split percussion core with a handheld penetrometer, was also similar to previously measured values (Tulaczyk and others, 2001), with $2 \mathrm{kPa}$ near the core top and rising to $\sim 6 \mathrm{kPa}$ at $0.2 \mathrm{~m}$ below surface. At this point we have no observational basis to decide if these sediments are true glacial tills, i.e. have been brought to the location where they were sampled by ice, or represent till material that has been redeposited by subaqueous flows in the lake basin. Such redeposition has been proposed to be one of the leading mechanisms for sub-ice sedimentation in SLW (Bentley and others, 2013).

No clear evidence of sedimentation from settling is present in the collected SLW cores, although we observed abundant suspended particles in subglacial water. One interpretation is that this water turbidity resulted from hotwater drilling through debris-laden basal ice. Christoffersen and others (2010) estimated that basal ice of the neighboring Kamb Ice Stream contains debris equivalent to a $\sim 2$ m-thick sediment layer. However, the lack of positive evidence for coarse sediment settling at the bottom of the lake (Fig. 3) favors the alternative explanation that lake water was turbid even before drilling. Similarly, the lack of a coarse lag on the sampled lake floor indicates that influx of subglacial water into the borehole at the time of its completion either did not mobilize bottom sediments or did it only over an area small enough for the coring to miss the disturbed zone (Fig. 2).

High turbidity is common in glacially fed streams and lakes (e.g. Milner and Petts, 1994), so it would not be surprising if SLW water is turbid in its natural state. Detailed particle-size analyses of till samples from upstream of SLW demonstrated that $20-25 \%$ of these sediment samples were smaller than $0.5 \mu \mathrm{m}$ (Tulaczyk and others, 1998). Such fine particles may stay in suspension practically indefinitely, due to Brownian collisions with water molecules (Ramaswamy, 2001). Subglacial water entering SLW may bring very fine particles that do not settle out and leave no sedimentary signature at the lake bottom.

\section{CONCLUSIONS}

The WISSARD subglacial access borehole drilled in late January 2013 confirmed the presence of a subglacial water basin that had been previously inferred from satellite altimetry (Fricker and others, 2007) and surface geophysics (Christianson and others, 2012; Horgan and others, 2012). Pressure equilibration between the borehole and SLW took place within seconds, rather than minutes as it was observed by Engelhardt and Kamb (1997) in dozens of boreholes drilled to the bottom of Siple Coast ice streams. This difference indicates that subglacial hydrological conditions encountered by our borehole at SLW are not widespread in the region. SLW water is $\sim 100$ times less saline than sea water but almost an order of magnitude more saline than Subglacial Lake Vostok (Priscu and others, 1999; Siegert, 2000). Because borehole water was pumped down below the flotation level, $8-20 \mathrm{~m}^{3}$ of subglacial water rushed into the hole during breakthrough, helping to minimize the impact of drilling on SLW. Subglacial water was turbid, which may be its natural state. Cored SLW sediments do not contain macroscopic evidence of sediment rain-out from suspension but are diamictons with fine-grained matrix. Our main operational recommendation for similar future projects is to manage freezing at the top of a water-filled borehole by supplying heat during science operations.

\section{ACKNOWLEDGEMENTS}

This material is based upon work supported by the US National Science Foundation, Section for Antarctic Sciences, Antarctic Integrated System Science program as part of the interdisciplinary WISSARD (Whillans Ice Stream Subglacial Access Research Drilling) project. Additional funding for instrumentation development was provided by grants from the Gordon and Betty Moore Foundation, the National Aeronautics and Space Administration (Astrobiology and Cryospheric Sciences programs) and the US National Oceanic and Atmospheric Administration. We are particularly thankful to the entire drilling team from the University of Nebraska-Lincoln and the WISSARD traverse personnel for crucial technical and logistical support. The United States Antarctic Program enabled our fieldwork, and Air National Guard and Kenn Borek Air provided air support. The manuscript was improved as a result of insightful comments from two anonymous reviewers. 


\section{REFERENCES}

Bealtos S (2002) Collapse of floating ice covers under vertical loads: test data vs. theory. Cold Reg. Sci. Technol., 34(3), 191-207 (doi: 10.1016/S0165-232X(02)00004-6)

Beem LH, Tulaczyk SM, King MA, Bougamont M, Fricker HA and Christoffersen P (2014) Variable deceleration of Whillans Ice Stream, West Antarctica. J. Geophys. Res., 119(F2), 212-224 (doi: 10.1002/2013JF002958)

Bell RE, Studinger M, Shuman CA, Fahnestock MA and Joughin I (2007) Large subglacial lakes in East Antarctica at the onset of fast-flowing ice streams. Nature, 445(7130), 904-907 (doi: 10.1038/nature05554)

Bentley MJ, Christoffersen P, Hodgson DA, Smith AM, Tulaczyk S and Le Brocq AM (2013) Subglacial lake sediments and sedimentary processes: potential archives of ice sheet evolution, past environmental change, and the presence of life. In Siegert MJ, Kennicutt $\mathrm{MCl}$ and Bindschadler RA eds. Antarctic subglacial aquatic environments. (AGU Geophysical Monograph Series 192) American Geophysical Union, Washington, DC, 83-110

Bindschadler RA, King MA, Alley RB, Anandakrishnan $S$ and Padman L (2003) Tidally controlled stick-slip discharge of a West Antarctic ice stream. Science, 301(5636), 1087-1089 (doi: 10.1126/science.1087231)

Carter SP, Fricker HA and Siegfried MR (2013) Evidence of rapid subglacial water piracy under Whillans Ice Stream, West Antarctica. J. Glaciol., 59(218), 1147-1162 (doi: 10.3189/ 2013JoG13J085)

Christianson K, Jacobel RW, Horgan HJ, Anandakrishnan S and Alley RB (2012) Subglacial Lake Whillans - ice-penetrating radar and GPS observations of a shallow active reservoir beneath a West Antarctic ice stream. Earth Planet. Sci. Lett., 331-332, 237-245 (doi: 10.1016/j.epsl.2012.03.013)

Christner BC and 9 others (2006) Limnological conditions in Subglacial Lake Vostok, Antarctica. Limnol. Oceanogr., 51(6), 2485-2501 (doi: 10.4319/lo.2006.51.6.2485)

Christoffersen P, Tulaczyk S and Behar A (2010) Basal ice sequences in Antarctic ice stream: exposure of past hydrologic conditions and a principal mode of sediment transfer. J. Geophys. Res., 115(F3), F03034 (doi: 10.1029/2009JF001430)

Cuffey KM and Paterson WSB (2010) The physics of glaciers, 4th edn. Butterworth-Heinemann, Oxford

Dowdeswell JA and Siegert MJ (2002) The physiography of modern Antarctic subglacial lakes. Global Planet. Change, 35(3-4), 221-236 (doi: 10.1016/S0921-8181(02)00128-5)

Engelhardt H (2004) Thermal regime and dynamics of the West Antarctic ice sheet. Ann. Glaciol., 39, 85-92 (doi: 10.3189/ 172756404781814203)

Engelhardt H and Kamb B (1997) Basal hydraulic system of a West Antarctic ice stream: constraints from borehole observations. J. Glaciol., 43(144), 207-230

Fisher AT and 12 others (2003) Hydrothermal recharge and discharge across $50 \mathrm{~km}$ guided by seamounts on a young ridge flank. Nature, 421(6923), 618-621 (doi: 10.1038/ nature01352)

Fricker HA and Scambos T (2009) Connected subglacial lake activity on lower Mercer and Whillans Ice Streams, West Antarctica, 2003-2008. J. Glaciol., 55(190), 303-315 (doi: 10.3189/002214309788608813)

Fricker HA, Scambos T, Bindschadler R and Padman L (2007) An active subglacial water system in West Antarctica mapped from space. Science, 315(5818), 1544-1548 (doi: 10.1126/ science.1136897)

Fricker HA and 13 others (2011) Siple Coast subglacial aquatic environments: the Whillans Ice Stream Subglacial Access Research Drilling Project. In Siegert MJ, Kennicutt $\mathrm{MCl}$ and Bindschadler RA eds. Antarctic subglacial aquatic environments. (Geophysical Monograph Series 192) American Geophysical Union, Washington, DC, 199-219

Gray L, Joughin I, Tulaczyk S, Spikes VB, Bindschadler R and Jezek $\mathrm{K}$ (2005) Evidence for subglacial water transport in the West
Antarctic Ice Sheet through three-dimensional satellite radar interferometry. Geophys. Res. Lett., 32(3), L03501 (doi: 10.1029/2004GL021387)

Heesemann $M$, Villinger $H$, Fisher AT, Tréhu AM and White $S$ (2006) Data report: testing and deployment of the new ACPCT-3 tool to determine in situ temperatures while piston coring. Proc. Integr. Ocean Drill. Prog., 311, 1-8 (doi: 10.2204/lodp.proc. 311.108.2006)

Hodgson DA and 11 others (2009) Exploring former subglacial Hodgson Lake, Antarctica Paper ii: palaeolimnology. Quat. Sci. Rev., 28(23-24), 2310-2325 (doi: 10.1016/j.quascirev. 2009.04.014)

Horgan HJ and 7 others (2012) Subglacial Lake Whillans - seismic observations of a shallow active reservoir beneath a West Antarctic ice stream. Earth Planet. Sci. Lett., 331-332, 201-209 (doi: 10.1016/j.epsl.2012.02.023)

Koci BR (1984) Hot water drilling in Antarctic firn, and freezing rates in water-filled boreholes. CRREL Spec. Rep. 84-34, 101-103

MacGregor JA, Winebrenner DP, Conway H, Matsuoka K, Mayewski PA and Clow GD (2007) Modeling englacial radar attenuation at Siple Dome, West Antarctica, using ice chemistry and temperature data. J. Geophys. Res., 112(F3), F03008 (doi: 10.1029/2006JF000717)

Maule CF, Purucker ME, Olsen N and Mosegaard K (2005) Heat flux anomalies in Antarctica revealed by satellite magnetic data. Science, 309(5733), 464-467 (doi: 10.1126/ science.1106888)

Milner AM and Petts GE (1994) Glacial rivers: habitats and ecology. Freshwater Biol., 32(2), 295-307 (doi: 10.1111/j.1365-2427. 1994.tb01127.x)

Niskin SJ, Segar DA and Betzer PR (1973) New Niskin sampling bottles without internal closures and their use for collecting near bottom samples for trace metal analysis. EOS, 54(11), 1110

Priscu JC and 11 others (1999) Geomicrobiology of subglacial ice above Lake Vostok, Antarctica. Science, 286(5447), 2141-2144 (doi: 10.1126/science.286.5447.2141)

Priscu JC, Tulaczyk S, Studinger M, Kennicutt MCI, Christner BC and Foreman CM (2008) Antarctic subglacial water: origin, evolution and ecology. In Vincent W and Laybourn-Parry J eds. Polar lakes and rivers: limnology of Arctic and Antarctic aquatic ecosystems. Oxford University Press, Oxford, 119-135

Priscu J, Powell RD and Tulaczyk S (2010) Probing subglacial environments under the Whillans Ice Stream. Eos, 91(29), 253-254 (doi: 10.1029/2010EO290002)

Priscu JC and 12 others (2013) A microbiologically clean strategy for access to the Whillans Ice Stream subglacial environment. Antarct. Sci., 25(5), 637-647 (doi: 10.1017/ S0954102013000035)

Ramaswamy S (2001) Issues in the statistical mechanics of steady sedimentation. Adv. Phys., 50(3), 297-341 (doi: 10.1080/ 00018730110050617)

Rignot E, Mouginot J and Scheuchl B (2011) Ice flow of the Antarctic Ice Sheet. Science, 333(6048), 1427-1430 (doi: 10.1126/science.1208336)

Scambos TA, Haran TM, Fahnestock MA, Painter TH and Bohlander J (2007) MODIS-based Mosaic of Antarctica (MOA) data sets: continent-wide surface morphology and snow grain size. Remote Sens. Environ., 111(2-3), 242-257 (doi: 10.1016/ j.rse.2006.12.020)

Scherer RP, Aldahan A, Tulaczyk S, Possnert G, Engelhardt H and Kamb B (1998) Pleistocene collapse of the West Antarctic ice sheet. Science, 281(5373), 82-85 (doi: 10.1126/science.281. 5373.82)

Sea-Bird Electronics (2013) User's manual: Seasoft V2 - SBE data processing. Sea-Bird Electronics, Bellevue, WA http://www. seabird.com/pdf_documents/manuals/SBEDataProcessing_7 23.2.pdf

Seeberg-Elverfeldt J, Schlüter M, Feseker T and Kölling M (2005) Rhizon sampling of pore waters near the sediment/water 
interface of aquatic systems. Limnol. Oceanogr. Meth., 3, 361-371 (doi: 10.4319/lom.2005.3.361)

Shapiro NM and Ritzwoller MH (2004) Inferring surface heat flux distribution guided by a global seismic model: particular application to Antarctica. Earth Planet. Sci. Lett., 223(1-2), 213-224 (doi: 10.1016/j.epsl.2004.04.011)

Siegert MJ (2000) Antarctic subglacial lakes. Earth-Sci. Rev., 50(1-2), 29-50 (doi: 10.1016/S0012-8252(99)00068-9)

Siegert MJ (2005) Lakes beneath the ice sheet: the occurrence, analysis, and future exploration of Lake Vostok and other Antarctic subglacial lakes. Annu. Rev. Earth Planet. Sci., 33, 215-245 (doi: 10.1146/annurev.earth.33.092203.122725)

Siegert MJ, Tranter M, Ellis-Evans JC, Priscu JC and Lyons WB (2003) The hydrochemistry of Lake Vostok and the potential for life in Antarctic subglacial lakes. Hydrol. Process., 17(4), 795-814 (doi: 10.1002/hyp.1166)

Siegert MJ, Carter S, Tabacco I, Popov S and Blankenship DD (2005) A revised inventory of Antarctic subglacial lakes. Antarct. Sci., 17(3), 453-460 (doi: 10.1017/S0954102005002889)

Siegfried MR, Fricker HA, Roberts M, Scambos TA and Tulaczyk S (2014) A decade of West Antarctic subglacial lake interactions from combined ICESat and CryoSat-2 altimetry. Geophys. Res. Lett., 41(3), 891-898 (doi: 10.1002/ 2013GL058616)

Smith BE, Fricker HA, Joughin IR and Tulaczyk S (2009) An inventory of active subglacial lakes in Antarctica detected by ICESat (2003-2008). J. Glaciol., 55(192), 573-595 (doi: $10.3189 / 002214309789470879)$
Stearns LA, Smith BE and Hamilton GS (2008) Increased flow speed on a large East Antarctic outlet glacier caused by subglacial floods. Nature Geosci., 1(12), 827-831 (doi: 10.1038/ngeo356)

Stefan J (1891) Über die Theorie der Eisbildung, insbesondere über die Eisbildung im Polarmeere. Ann. Phys. [Berlin], 278(2), 269-286 (doi: 10.1002/andp.18912780206)

Tulaczyk S, Kamb B, Scherer RP and Engelhardt HF (1998) Sedimentary processes at the base of the West Antarctic ice stream: constraints from textural and compositional properties of subglacial debris. J. Sediment. Res., 68(3A), 487-496 (doi: 10.2110/jsr.68.487)

Tulaczyk SM, Kamb B and Engelhardt HF (2000) Basal mechanics of Ice Stream B, West Antarctica. I. Till mechanics. J. Geophys. Res., 105(B1), 463-481 (doi: 10.1029/1999JB900329)

Tulaczyk S, Kamb B and Engelhardt HF (2001) Estimates of effective stress beneath a modern West Antarctic ice stream from till preconsolidation and void ratio. Boreas, 30(2), 101-114 (doi: 10.1111/j.1502-3885.2001.tb01216.x)

WAIS Divide Project Members (2013) Onset of deglacial warming in West Antarctica driven by local orbital forcing. Nature, 500(7463), 440-444 (doi: 10.1038/nature12376)

Walter JI, Brodsky EE, Tulaczyk S, Schwartz SY and Pettersson R (2011) Transient slip events from near-field seismic and geodetic data on a glacier fault, Whillans Ice Plain, West Antarctica. J. Geophys. Res., 116(F1), F01021 (doi: 10.1029/2010JF001754)

Wingham DJ, Siegert MJ, Shepherd A and Muir AS (2006) Rapid discharge connects Antarctic subglacial lakes. Nature, 440(7087), 1033-1036 (doi: 10.1038/nature04660) 